Richard A. Cohen:

\title{
Plato, Judaism, Kant and Information Technology
}

\begin{abstract}
:
Plato's two complaints in the Phaedrus about the new technology of writing, namely, that reliance upon it leads to forgetfulness and fosters intellectual misunderstanding, which are here taken equally to be relevant. Possible complaints about contemporary information technology, are examined and assessed, in themselves and in relation to Jewish rabbinic exegetical tradition and in relation to Immanuel Kant's positive claims for text based religions in Religion within the Limits of Reason Alone.
\end{abstract}

\section{Agenda}

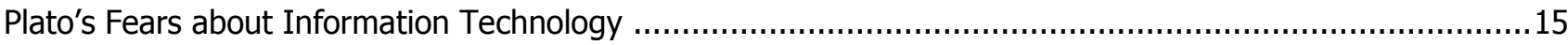

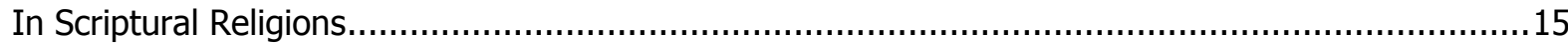

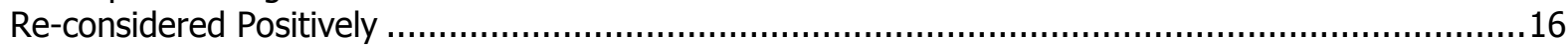

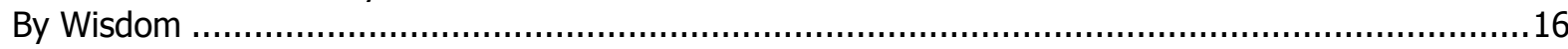

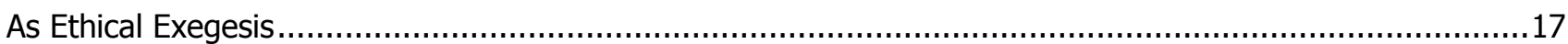

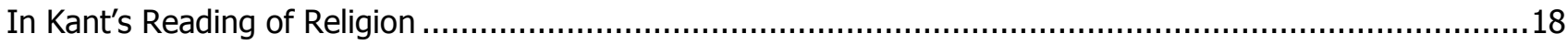

\section{Author:}

Dr. Richard A. Cohen

- Department of Philosophy, Institute of Jewish Thought and Heritage, College of Arts and Sciences, 810 Clemens Hall, University at Buffalo, Buffalo, New York 14260-4500, USA

- 716 645-2711; $\square$ : richacohen@aol.com; 皿: www.richacohen.com

- Relevant publications:

- Technology: The Good, the Bad and the Ugly. Postphenomenology: A Critical Companion to Ihde, Evan Selinger (Ed.). Albany, NY: State University of New York Press, 2006, pp. 145-160.

- Ethics and Cybernetics: Levinasian Reflections. Ethics and Information Technology, Spring 2000, Vol. 2, No. 1, pp. 27-35. 


\section{Plato's Fears about Information Technology}

In the Phaedrus Plato warns of two fundamental dangers of a then relatively new information and communication technology (IT): the written word. ${ }^{1}$ His reservations then apply even more now to our high speed, global, computer driven information technologies. Indeed, a sure sign of the continued relevance of his worries is precisely the fact that today we recoil almost instinctively from taking advice on a topic like this - contemporary computer technology - from a thinker so seemingly "out of date" as Plato. In today's constantly changing world a few years, a few months, even a few weeks can make a leading edge technology outmoded or obsolete. Nevertheless, the amazing speed of our new technologies and the unprecedented rapidity of their development have not overtaken Plato. What are the dangers Plato foresaw?

First, memory will diminish. The reification of meaningful signs into independent storable spatialtemporal symbolic representations (writing), leads to the deterioration of living humans' capacity to remember; it will "implant forgetfulness in their souls." 2 Second, misunderstanding will increase. Because externalized symbolic representations (on scrolls, in books, on internet websites) "go on telling you just the same thing forever" ${ }^{\prime 3}$ and facilitate solitary information retrieval (reading), true understanding will be overcome by erroneous interpretations undisciplined by any face-to-face dialogue/ dialectic of questioning and answering. In sum, IT will weaken our memory and warp our understanding.

If correct, and to the extent that they are correct, the consequences of Plato's two-pronged critique of IT for the continued significance of our social, cultural and political traditions are enormous. Jose Ortega y Gasset diagnosed several of these consequences in his book The Revolt of the Masses

${ }^{1}$ See, Plato, Phaedrus, trans. R. Hackforth, in Plato: The Collected Dialogues, ed. E. Hamilton and $\mathrm{H}$. Cairns (Princeton: Princeton University Press, 1999), 520-521 (275a-275e).

2 Plato, Phaedrus, 520 (275a).

3 Ibid., 521 (275d).
(1930), in which he wrote, tellingly: "The mass-man believes that the civilization into which he was born and which he makes use of, is as spontaneous and self-producing as Nature, and ipso facto he is changed into primitive man. ${ }^{4}$ Loss of memory, in other words, reaches to a forgetfulness of history: only the present is real, surrounded, perhaps, by the news of the last two weeks.

\section{In Scriptural Religions}

The consequences of the validity of Plato's twopronged critique for religious traditions based in sacred scriptures, that is to say, for religions based in exegesis and commentary, and thus for religions as globally significant as, say, Judaism, Christianity, Mormonism, Islam, Hinduism, Buddhism, Confucianism, and Taoism, are no less profound and frightening.

Indeed, the consequences for scripturally based religions are nothing less than revolutionary. For one, it would mean that contrary to the treasured belief of the faithful, reliance upon a sacred text would already represent the loss of a more pristine religious revelation. Scriptural revelation would be spiritual devolution. Instead of the familiar critique of IT which chides that the internet, with the vast availability of information it puts at our fingertips, reinforces our isolation and seduces us away from living religious community, scriptural learning and closeness to the divine, according to Plato's far more radical critique the scriptures would be themselves the original seduction and distraction away from true religious community and spiritual closeness to God. So the much clerically decried contemporary decline of traditional religious institutions in the West could, from this perspective, represent an overall gain for true religion, as found, for instance, in New Age spirituality or in evangelicalism (if it were not so obvious, on the contrary, that it usually represents the increased sway of a materialistic individualism).

On the other hand, this sounds quite a bit too clever, abstract and simplistic, indeed, it rings sophistical: sacred scripture as the unholy ${ }^{5}$ Plato's

\footnotetext{
4 Jose Ortega y Gasset, The Revolt of the Masses (New York: W.W. Norton, 1957), 89.

5 The Talmud has the exquisite spiritual audacity to declare that touching sacred scriptures makes one unclean! See, Babylonian Talmud, Sabbath, 14a.
} 
critique demands to be taken more seriously, demands that we examine more closely the complex and nuanced transformations of memory and truth both consequent and constitutive of writing. Perhaps it is precisely the scriptural religions, which take writing more seriously than any other human perspective, can best teach us how to properly qualify Plato's criticisms, how to see in the changes wrought by IT not simply the dystopia of loss and deformation, but rather an innovative contribution to a different and higher human spirituality. But how, accordingly, can what Plato feared most about writing - memory loss, meaning distortion - represent something positive, and especially something positive in relation to the deepest significations that are the true care of religious traditions?

\section{Re-considered Positively}

First, relative to memory loss, one can also see in IT a disburdening and liberation of the memory. Not, to be sure, in the sense that humanity need no longer know by remembering and embodying truths. The mass-man Ortega feared, the one who takes civilization for granted like nature, remains a genuine worry. To know genuinely remains a knowing of one's own, an existential self-enrichment. But the technology of information storage can better ensure that vast amounts of data - the documentary record of whole civilizations - can be preserved come what may, earthquakes, hurricanes, fires, floods, etc. Even if for whatever reasons humans do forget or lose vital information, it can be regained because of its having been preserved in objective forms. In preliterate societies, in contrast, information forgotten to living memory is lost irretrievably, gone forever. At best is might be discovered anew.

Judaism, certainly, has treasured its written Torah as writing. The very writing of it is a holy act performed with an unequaled meticulousness and piety. Israelite kings are obligated, according to the Hebrew Bible, to write out two copies of their own, must always carry one on their person, and are enjoined "to read from it all the days of his life" (Leviticus 17:18-19). The Hebrew Bible even has the audacity to speak of its own loss and retrieval: The young King Josiah, grandson of the faithful King Hezekiah and son of the idolatrous King Manasseh, first learns of it and reads aloud from it to the Israelites from a Torah scroll found in the Temple of Jerusalem by the High Priest (II Kings 22:8-23:2). So, too, after the Israelites returned from Babylonian captivity, Ezra the Scribe read and expounded to them the Torah that they had forgotten while in exile (Nehemiah 8:1-9:3). For this communal re- newal of the covenant the Talmud likens Ezra to a "second Moses. More profoundly still, and as if in response to Plato's second fear, Judaism complements its Written Torah (Torah she-bikhtav) with its Oral Torah (Torah she-be'al peh) - both understood to have been given by God at Mount Sinai.

Regarding Plato's second fear, namely, that by detaching signs from the living persons signifying them IT encourages a freedom for misinterpretations, falsehoods, ersatz wisdom, here too one can accept Plato's insight but temper it with a very different and positive alternative. One can see in this same freedom deriving from the differential ambivalence of signs not just an interpretive free for all, but rather the unfathomably rich source for multiple readings growing and building upon themselves to form a specific tradition kept alive and ever fructified through exegetical amplification. This is certainly, in any event, how the scriptural religions unfold and maintain their integrity across the changing emphases of historically situated discourse.

\section{By Wisdom}

To properly understand this crucial difference between unregulated interpretative license, with its loss of historical development, and the rigors of an exegetical tradition, we must first make explicit the underlying premise of both of Plato's criticisms, and then show how this premise is understood by religious traditions in contrast to its philosophical appropriation. Very simply, Plato's underlying premise is that one can and must distinguish between opinion and knowledge, information and understanding, ignorance and wisdom.

In a preliminary way let us characterize philosophical wisdom as data humanly interpreted and integrated by reason into a holistic (though not necessarily a whole) worldview. If one imagines - for heuristic purposes - a continuum of symbolic signs, with mathematical symbols at one end, the "object" side, wisdom would lay toward the far other side, the "subject" side. But for Plato and scriptural religion wisdom is not subjective, but more objective, as it were, than the objectivity of numbers. It is not more objective because it can be measured, to be sure, but because it is more important, worthier of humans, closer, as Plato thought, to the eternal and absolute good that should direct human behavior and thinking. Of course neither side of the continuum is completely pure, since numbers must take on a material form, and wisdom remains in some sense cut to the measure of finite human sensibility, and both, furthermore, necessarily involve elements 
of selection. Still, from this perspective we can now better understand Plato's critique of writing: by detaching signs from wise persons it sets them adrift from the discernment necessary to distinguish and value truth above falsehood, the important above the trivial, the revealing above the merely logical, and ultimately the good above evil. Signs by themselves can signify anything, as contemporary postmodern deconstructive practices demonstrate all too well. Signs are bound to truth through wise discernment.

The wise person is not, therefore, simply someone with a lot of information in their head. A computer can hold information, though it can never be wise. Rather, the wise person's wisdom is an embodied teaching, and the wise person is both a student and a teacher. Wisdom occurs, happens, transpires, is born and dies across a face-to-face relationship, as a social event, even if it is sparked by the solitary reading of the ancient books of "dead white males." For Plato, in other words, dialogue is not a luxury or a distraction but the very situation of truth, the testing ground and channel, as it were, of the truth of truth. His teacher, Socrates, philosophized but did not write at all. And Plato was only able to "write" philosophy in the form of dialogue, the form best suited, so it seems, to obviate the inherent dangers of IT. Because the written symbolic representation of what counts most, i.e., wisdom, is "unable to defend or help itself, ${ }^{\prime \prime}$ is unable to clarify or expound its proper sense, is unable to prevent or mitigate false readings and misunderstanding, the living presence of a wise person is required.

Independent of their communicative context, conversely, signs lend themselves to endless manipulation, so that the better can appear worse and the worse better, or the true false and the false true, and ultimately so that signs mean everything and nothing - or, as Nietzsche better expressed it, they become "a book for all and none." ${ }^{17}$ Writing or IT, detached from wisdom, promotes sophistry. Sophistry is not simply the product of evil minded persons; it lies in the seduction, the sirens' call of words. This does not mean, however, that the remedy must

\footnotetext{
${ }^{6}$ Plato, Phaedrus, 521 (275e).

${ }^{7}$ Ein Buch für Alle und Keinen - these words are of course the subtitle of Nietzsche's most personal book, Thus Spoke Zarathustra.
}

come from some doctrine of "original intent," as if what is meant by an author is privileged as such. We know that Plato was especially hard on poets because he did not believe that as poets that they were the best interpreters of their own poetry, just as later Spinoza will argue that prophets, Daniel for example, are not the best interpreters of their own prophecies. Rather, he is saying that outside of its communicative context involving expository and argumentative interchange between teacher and student, the presence of writing, or a website filled with words, leaves open too many meanings to discern true meanings and to lead to genuine understanding. Wisdom emerges only through dialogue, conversation, discussion, communication, where what is said (what can be recorded externally) can be clarified, unraveled, sharpened, revised, refined, corrected, and otherwise submitted to an essentially social verification procedure, even in unresolved inquiries (Plato's Euthyphro, for example). This process, however, can be evaded or forgotten in the virtually solitary retrieval of the almost anonymous and seemingly infinite information sources made available by today's computer technologies. Many are the teachers who lament how often their students mistake Wikipedia for wisdom.

\section{As Ethical Exegesis}

How, then, having said all this, can we suggest that in writing, and in IT more broadly, Plato's fears can be mitigated? How is it possible that the multiplication of meaning to which writing as writing is prone, can be seen to be something positive rather than the source of misunderstanding, confusion, and ultimately of the loss of meaning altogether? Plato has already pointed us toward the answer: in the communication situation, in dialogue. But his philosophical notion of a single or unified, non-contradictory, ideal, eternal, and unchanging truth led him astray, or rather exacerbated his fears. Scriptural religions, in contrast, provide us a better or more specific guide and model: in the communicative situation as an exegetical tradition arising from an essentially pluralizing sacred text. And Judaism gives us a concrete instance: the exegetical integrality and authority of its Written Torah inextricably bound to Oral Torah. Two elements are central to all of these answers which bind IT to wisdom: the writing or text, and the disciplining of the multiplication of meaning to which writing necessarily, as writing, gives rise. This discipline is what in religion is called "exegesis" or "tradition." Exegesis, in other words, is the positive alternative response to Plato's otherwise well justified cautions. 
I have elaborated on this theme in my book, Ethics, Exegesis and Philosophy. There I defend the thesis that the meanings which count, the symbolic representations through which "wisdom" is achieved, do not depend on the univocal and exclusionary definitions which Plato has Socrates seeking, but rather and precisely on a multiplicity of non-exclusionary interpretations. This multiplicity, rather than deriving from and leading to misunderstanding and nonsense, reflects the multiplicity of interlocutors necessary to wisdom. The communicative context is not a sort of temporary ladder, as it were, to be discarded after rising through argumentation to absolute ideas which transcend the human condition altogether. Indeed, the auxiliary and secondary status accorded to the communicative context derives from what scholars have identified as Plato's "theory of ideas," whereby primacy is given solely to knowledge conceived in the light of a (impossible) disembodied mathematical ideal. If we are to take seriously Socrates' alleged turn from the natural sciences to a quest for the good, to "ethics as first philosophy," to use Emmanuel Levinas's expression, then the communicative context - dialogue, discussion, conversation - far from being a disposable prolegomena to a pure knowledge, changes status to become part and parcel of wisdom itself. Thus, so I argued in my book, philosophy should learn from religious exegesis the method of what I dubbed "ethical exegesis." In my book I summed this is as follows: "We must distinguish in exegesis four inter-related characteristics or dimensions: (1) concrete and productive integrity of spirit and letter; (2) pluralism of persons and readings; (3) virtue, or existential, selftransformative wisdom; and (4) authority, or the renewal of a living ethico-religious tradition., ${ }^{\prime 8}$

\section{In Kant's Reading of Religion}

But instead of revisiting my book to elaborate the positive value of IT in the face of Plato's fears, here I will conclude by turning to a similar line of thought found in the philosophy of Immanuel Kant, in one of his last works, Religion within the Limits of Reason Alone (1793; $2^{\text {nd }}$ ed., 1794). Though Kant developed an enormously influential philosophy of science in his most famous work, The Critique of Pure Reason $\left(1781 ; 2^{\text {nd }}\right.$ ed., 1787), he himself gave "primacy" to his second critique on ethics, The Critique of Practi-

${ }^{8}$ Richard A. Cohen, Ethics, Exegesis and Philosophy: Interpretation After Levinas (Cambridge: Cambridge University Press, 2001), 246. cal Reason (1788). The primacy given to ethics over knowledge also determines Kant's conception of enlightened religion in Religion within the Limits of Reason Alone, where ecclesiastic faith is meant to serve ethics, indeed, to function as the historically concrete propaedeutic to a globally just sociality. But our specific interest in Kant's book on religion lies in what it says about scripture.

In a long footnote appended to the end of Part Three, Kant makes the following peculiar observation: "Yet a people which has a written religion (sacred books) never fuses together in one faith with a people (like the Roman Empire, then the entire civilized world) possessing no such books but only rites; instead, sooner or later it makes proselytes. ${ }^{\prime \prime}$ He gives as the reason for the resilience of scriptural religions what we have already indicated above: if lost, such writings can be found and can revitalize. But, again as we have also indicated above, this restorative power is not the deepest significance of the scriptural basis of religion for Kant.

More profoundly, the scriptures fructify through their interpretation, through exegesis. Because scriptural religions have books, writings, and because writing, as Plato worried, opens itself to diverse readings, exegesis can guide ecclesiastical faiths across historical peregrinations to maintain their true purpose, which is, as Kant succinctly puts it, "to make men better. ${ }^{\prime 10}$ Scriptures thus at once both liberate and restrict. Kant, faithful to the primacy of practical reason, determines the latter in terms of moral edification.

Hence, even if a document is accepted as a divine revelation, the highest criterion of its being of divine origin will be: 'All scripture given by inspiration of God is profitable for doctrine, for reproof, for improvement, etc.' (James II, 17); and since this last, to wit, the moral improvement of men, constitutes the real end of all religion of reason, it will comprise the highest principle of all Scriptural exegesis. ${ }^{11}$

9 Immanuel Kant, Religion within the Limits of Reason Alone, trans. T. M. Greene and H.H. Hudson (New York: Harper and Row, 1960), 127.

\footnotetext{
${ }^{10}$ Kant, Religion, 102

${ }^{11}$ Ibid., 102
} 
[A]n exposition of the revelation which has come into our possession is required, that is, a thorough-going interpretation of it in a sense agreeing with the universal practical rules of a religion of pure reason. For the theoretical part of ecclesiastical faith cannot interest us morally if it does not conduce to the performance of all human duties as divine command (that which constitutes the essence of all religion). ${ }^{12}$

And even more concretely (and despite the ideology of Christian supersessionism which elsewhere mars Kant's understanding of Judaism), he writes:

The later Judaism, and even Christianity itself, consist of such interpretations, often very forced, but in both instances for ends unquestionably good and needful for all men. ${ }^{13}$

Kant justifies the centrality of scriptures as sources of interpretation, even when these interpretations seem "forced," on two grounds. First, on the "possibility that their authors may be so understood, ${ }^{\prime 14}$ which flexibility is precisely facilitated by their character as writings about which Plato warned. And second, most importantly, on the ultimate aim of religion and "the highest criterion" of a text "being of divine origin," namely, "to make men better." This latter criterion provides the needed discipline to harness an otherwise wild interpretive freedom and to limit an otherwise unregulated and ultimately belligerent sophistry which Plato feared most.

Thus ethical exegesis, as dialogue with text and dialogue between readers, represents one positive and pacific response to Plato's justified fears, a positive way to put to good purpose the undeniable multiplication of significations released by writing as such, or, as we would say today, by the technologies of information storage and retrieval. Scriptural interpretive tradition is thus not only one way to preserve the heritage of a religious community, it is also able to propel such a community - as an assembly of speakers and hearers, teachers and learners, passing from one generation to the next from and toward an ever more profound and growing wisdom.

\footnotetext{
${ }^{12}$ Ibid., 100

${ }^{13}$ Ibid., 102

${ }^{14}$ Ibid., 102
}

\section{References}

Cohen, R.A.: Ethics, Exegesis and Philosophy: Interpretation After Levinas. Cambridge: Cambridge University Press 2001.

Kant, I.: Religion Within the Limits of Reason Alone. trans. T. M. Greene and H.H. Hudson. New York: Harper and Row 1960.

Ortega y Gasset, J.: The Revolt of the Masses. New York: W.W. Norton 1957.

Plato, The Collected Dialogues, ed. E. Hamilton and H. Cairns. Princeton: Princeton University Press, 1999 